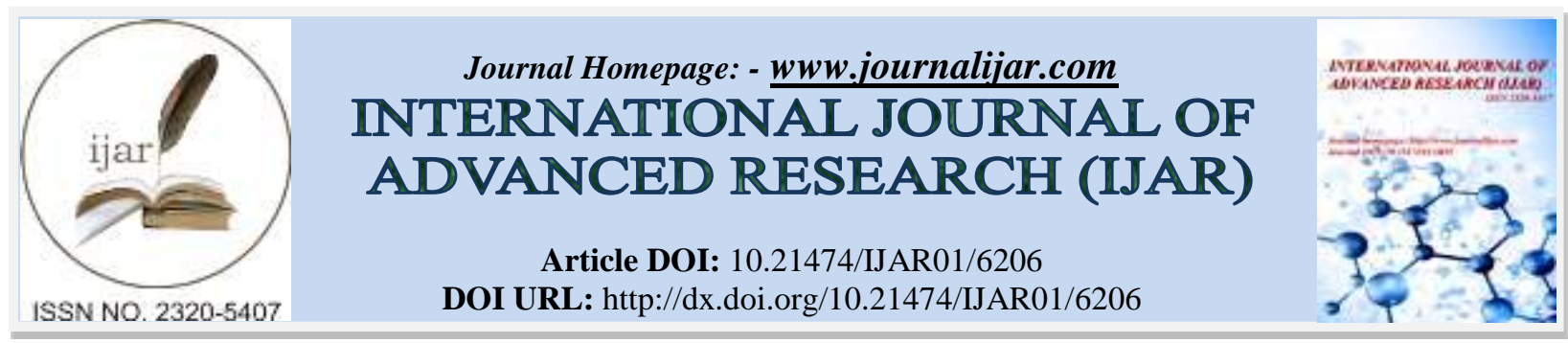

RESEARCH ARTICLE

\title{
MORPHOLOGICAL IDENTIFICATION OF TROPHIC TRIBOLIUM CASTANEUM POPULATIONS HERBST (COLEOPTERA, TENEBRIONIDAE) IN WEST AFRICA.
}

\section{*Cheikh Abdou Khadre Mbacké Dia ${ }^{1,2,3}$, Adiouma Georges Robert Jacques Sarr ${ }^{1,2,3}$, Ange Kafom 1,2, Déthié} Ngom $^{1,2}$, Toffène Diome ${ }^{1,2,3}$, Cheikh Thiaw ${ }^{4}$, Saliou Ndiaye ${ }^{5}$ and Mbacké Sembene ${ }^{1,2,3}$.

1. Département de Biologie animale, Faculté des sciences et Techniques, Université cheikh Anta DIOP de Dakar. B.P. 5005 Dakar, Sénégal.

2. Laboratoire d'Entomologie et d'Acarologie, Département de biologie Animale, Faculté des sciences et techniques, Université Cheikh Anta DIOP de Dakar. B.P. 5005 Dakar, Sénégal.

3. Laboratoire de Biologie des Populations Animales Sahélo-Soudaniennes (BIOPASS). Institut de recherche pour le développement (IRD) / Institut Sénégalais de Recherche Agricole (ISRA) Bel-Air B.P. 1386, Dakar, Sénégal.

4. CNRA de Bambey, Diourbel -PO 211, Sénégal.

5. ENSA de Thiès, Thiès $-\mathrm{N} 3$, Sénégal.

\section{Manuscript Info}

\section{Manuscript History}

Received: 03 November 2017

Final Accepted: 05 December 2017

Published: January 2018

Key words:-

Tribolium castaneum, trophic population, ACP, morphometry, $\mathrm{CAH}$, West Africa.

\section{Abstract}

Tribolium castaneum, the primary pest of stored commodities, is a cosmopolitan and polyphagous beetle. Its ability to unfold its development cycle on various food substrates has led to reflections on its morphological adaptability. This study aimed to identify morphologically $T$. castaneum populations in the West African zone. In each West African country, two populations were defined according to the cereal (millet or rice) on which $T$. castaneum unfolded its development cycle. Each of the populations consists of 30 adult males. On each adult, 19 variables were measured. The distances between the eyes dorsally and ventral ( $D y d, D y v)$, the width of the femur_3 (lf3) are eliminated from the analysis because they do not present any variability between the different individuals. The remaining 16 variables are used for Principal Component Analysis (PCA) and Discriminant Analysis (DA). Size is the first factor that discriminates between millet and rice trophic populations in all West African countries. Following the logarithmic transformation of the data, the biplots (PCA and DA) showed a difference in form between these two populations. Most of the transformed log-variables revealed significant mean differences between the two trophic populations in all West African countries. The hierarchic classification ascendant (HCA) combined the morphology of almost all individuals in the millet trophic population with that of group _1 and the morphology of most individuals in the rice trophic population with that of morphological groups $\_2$ and $\_3$. There is a morphological structure of $T$. castaneum populations in the West African zone. These observed differences would probably be related to a morphological adaptation of individuals or the phenotypic expression of new mutants. 


\section{Introduction:-}

With a significant reduction in rainfall forecast by the World Bank (World Bank, 2007) in the Sahelo-Sudanese zones for the coming decades, climatic hazards may make water availability a constraining factor in achieving food security. Among the solutions recommended to deal with these climatic hazards is the valorization of the cultivation of certain cereals, particularly millet and irrigated rice. Notably, millet or Pennisetum typhoides, the most tolerant and drought resistant cereal, and grown in arid and semi-arid regions of Africa where rainfall is between 150 and $800 \mathrm{~mm}$ isohyets (FAO, 1996), is one of the far-reaching crops for undermining food security in the West African zone. The availability of this cereal, its adaptation to the different agro-ecological zones of West African countries and its adaptation to a wide range of uses, justify the primordial role it plays in food security (AFD-CIRAD-IFAD, 2011). In addition to this grass, the valorization of rice cultivation by irrigation has also become one of the major solutions to counteract the negative impact of climate change on food security, especially since sub-Saharan Africa has a significant irrigable potential, favorable to this type of crop, which is largely more profitable than rainfed rice (yield of rainfed rice $=1.04$ tonnes $/$ ha, irrigated rice yield $=4.19$ tonnes $/$ ha) (AFD-CIRAD-IFAD, 2011). these two foodstuffs suffer a bottleneck at two levels: production and marketing. Among the causes of the latter, we can mention the lack of storage infrastructure that leads to poor storage conditions for these cereals leading to significant quantitative and qualitative losses. Given the seasonal cereal crop in West Africa, grain storage is imperative to meet seed requirements for the next growing season and to ensure food security. These stocks suffer enormous losses both quantitatively and qualitatively, with up to 20 to $30 \%$ losses of millet and rice stored (Ngamo\& Hance 2007) after six months of poor storage (AFD-CIRAD-IFAD, 2011). Theses post-harvest cereal losses are estimed, before precessing; at $10-20 \%$ of the crop stored, which corresponds to approximately $\$ 4$ billion, representing $13 \%$ of the total value of again production in the sahelian countries. Insect pests are responsible for 44\% (Foua-Bi 1989, Sezonlin 2006) and Tribolium castaneum is the most damaging to stocks. Insect reputed by its great polyphagia ${ }^{1}$ (Delobel\& Tran, 1993), T. castaneum also attacks cereals (millet, rice, maize ...) and legumes (Seck, 2012). Knowing that if living things transform morphologically, it is to adapt to the changes in their environment, the ability of $T$. castaneum to unfold its development cycle on different food media, has sparked reflections on its morphological adaptability to these different cereals offer different food resources and optimal survival conditions (Diome, 2014). The ability of this insect to perform well its development cycle on different host plants can promote trophic specialization of both morphological and genetic populations. This specialization could be the result of a strong morphological and genetic diversity between populations, and the feeding of the insect is one of the main drivers of this diversity. This article focuses on the morphological aspect of $\mathrm{T}$. castaneum diversity. for this, the impact of different host plants on the morphology of this insect will be evaluated in order to detect a morphological adaptation trophic populations of T. castaneum in the West African zone.

\section{Methodology:-}

Sampling: During sampling, large and medium-sized agricultural traders, marketing their products wholesale, semiwholesale and / or retail in urban markets, were targeted. In their shops, millet and locally grown irrigated rice are stored for most of the dry season. These aforementioned storage conditions are common in all sampled stores. Small quantities of millet and rice are collected from stores that are located in urban markets in Niger (Niamey Urban Market), Gambia (Banjul: $13^{\circ}$ ), Burkina Faso (Bobo-Dioulasso Central Market), Mali (Bamako Market: $12^{\circ}$ ), in the Republic of Guinea (Boussoura de Conakry Market), in Guinea Bissau (Urban Market of Bissau) and Senegal (Dahra Dioloff) (Figure 1). The quantities of cereals collected are put in plastic bags and sent to the laboratory.

\footnotetext{
${ }^{1}$ Ability to develop and to place its cycle of development on different host plants.
} 


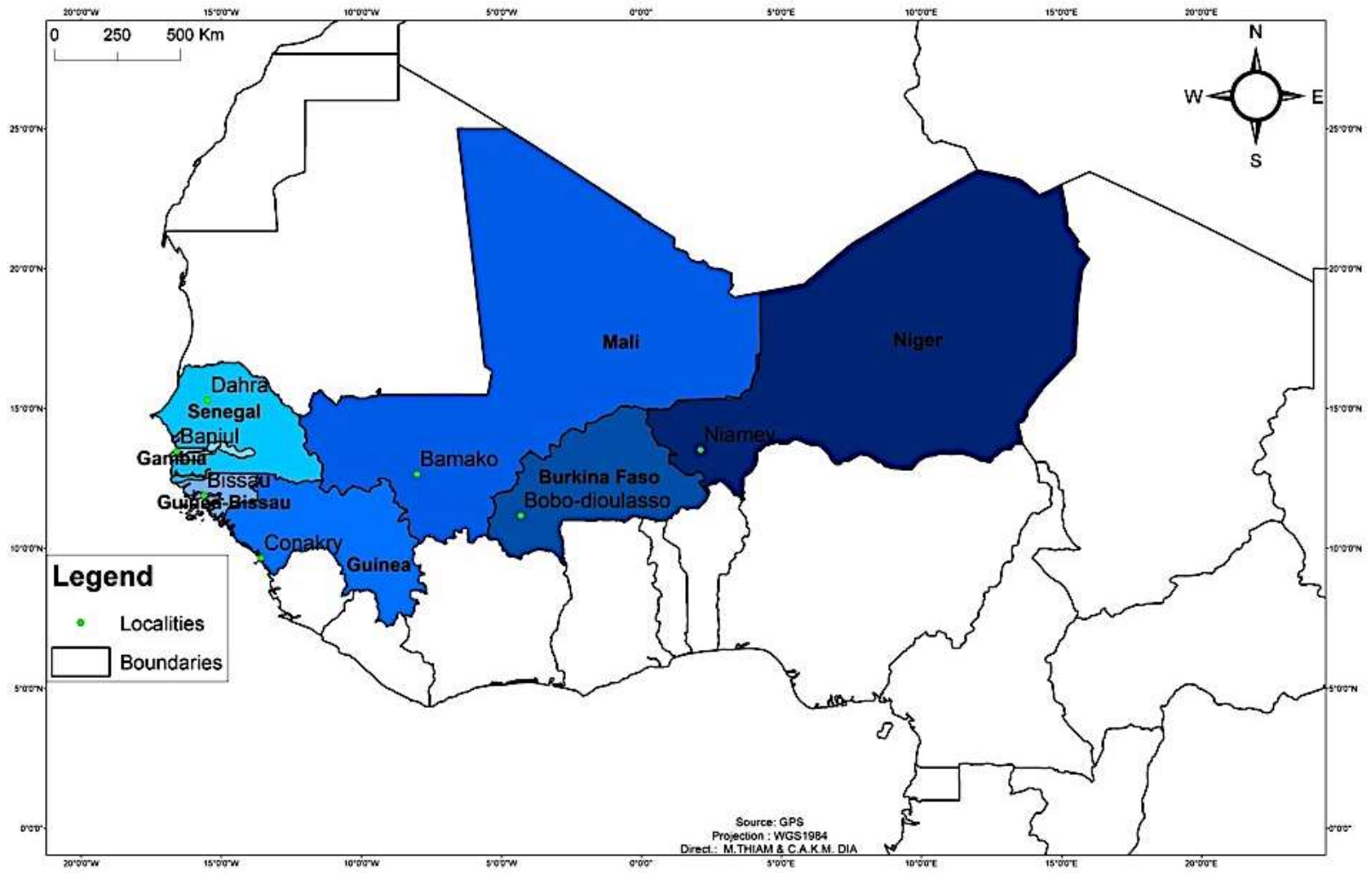

Figure 1:- Geographical distribution of sampled T. castaneum populations sites

The quantities of collected cereals were put in plastics bags and directed to the laboratory.

Mass rearing: samples are transferred into glass jars with holes and lids covered with mosquito netting to provide aeration system for the insect population contained in the speculation and at the same time to create a kind of barrier to prevent emerging adults from leaving the farm after maturation. Thirty first-generation adults emerging from mass rearing are retrieved for each population (Table 1).

Table 1:- Analyzed samples, NI (Niger), Se (Senegal), Ga (Gambia), Bu (Burkina Faso), Ma (Mali), GC (Guinea Conakry), Gb (Guinea Bissau); ml (Millet), rz (rice).

\begin{tabular}{|l|l|l|l|}
\hline & & \multicolumn{2}{l|}{ Code of the Insect (number of individuals) } \\
\hline The concerned countries & Geographic coordinates & Millet & Rice \\
\hline Niger (Niamey) & $13^{\circ} 30^{\prime} 49^{\prime \prime} \mathrm{N}, 02^{\circ} 06^{\prime} 35^{\prime \prime} \mathrm{E}$ & TcmlNi (30) & TcrzNi (30) \\
\hline Senegal (Dahra) & $15^{\circ} 21^{\prime} 00^{\prime \prime} \mathrm{N}, 15^{\circ} 29^{\prime} 00^{\prime \prime} \mathrm{O}$ & TcmlSe (30) & TcrzSe (30) \\
\hline Gambia (Banjul) & $13^{\circ} 27^{\prime} 00^{\prime \prime} \mathrm{N}, 16^{\circ} 34^{\prime} 59^{\prime \prime} \mathrm{O}$ & TcmlGa (30) & TcrzGa (30) \\
\hline B. Faso (Bobo-Dioulasso) & $11^{\circ} 10^{\prime} 37^{\prime \prime} \mathrm{N}, 04^{\circ} 17^{\prime} 52^{\prime \prime} \mathrm{O}$ & TcmlBu (30) & TcrzBu (30) \\
\hline Mali (Bamako) & $12^{\circ} 39^{\prime} 00^{\prime \prime} \mathrm{N}, 08^{\circ} 00^{\prime} 00^{\prime \prime} \mathrm{O}$ & TcmlMa (30) & TcrzGc (30) \\
\hline R. Guinea (Conakry) & $09^{\circ} 32^{\prime} 16^{\prime \prime} \mathrm{N}, 13^{\circ} 40^{\prime} 38^{\prime \prime} \mathrm{O}$ & TcmlGc (30) & TcrzMa (30) \\
\hline Guinea (Bissau) & $11^{\circ} 52^{\prime} 01^{\prime \prime} \mathrm{N}, 1536^{\prime} 00^{\prime \prime} \mathrm{O}$ & TcmlGb (30) & TcrzGb (30) \\
\hline
\end{tabular}

\section{Morphometric study:-}

Morphometric study: The biological material used consists of $T$. castaneum males that emerged after mass rearing on millet and rice. Only males are used to avoid the bias that some pregnant females may have on the measurements during their conservation. The insect was fixed with needles on the graph paper placed in the field of view of the illuminated magnifying glass. The insect is dissected by first separating its three parts namely the head, the thorax and the abdomen. Then each part was dissected in turn by separating the different elements that constitute it. These are then measured using graph paper. Nineteen (19) parameters were measured on each individual (Table 2). 
Table 2:- Different parameters measured and grouped according to the concerned party of the Insect

\begin{tabular}{|l|l|}
\hline Parties & Articles measured \\
\hline Head & $\begin{array}{l}\text { Length of the antenna }(L m A) \text {, minimum distance between dorsally eyes }(D y d) \text {, minimum distance } \\
\text { between ventrally eyes }(D y v), \text { maximum length of the head }(L m t), \text { maximum width of the head }(l m t)\end{array}$ \\
\hline Thorax & $\begin{array}{l}\text { Length of the pronotum in the center }(L p), \text { width of the pronotum }(l p) \text {, distance between the pronotum } \\
\text { and the Thorax }(D p t), \text { Femur Length } 3\left(L f_{3}\right), \text { width of the femur } 3\left(l f_{3}\right) \text {, length of the tibia } 3\left(L t i_{3}\right), \\
\text { length of the coxa } 3\left(L c_{3}\right), \text { length of the tarsus } 3\left(L t a_{3}\right) \text {, maximum length of the elytron }(L m e ́), \\
\text { maximum width of the elytron }(l m e ́)\end{array}$ \\
\hline Abdomen & $\begin{array}{l}\text { Maximum length of the first abdominal sternite }\left(L_{l} s\right) \text {, maximum width of the first abdominal sternite } \\
\left(l_{l} s\right), \text { maximum length of the pygidium }(L p y), \text { maximum width of the pygidium }(l p y) .\end{array}$ \\
\hline
\end{tabular}

\section{Statistical analyzes:-}

Choice of the number $\mathbf{Q}$ of factorial axis - $\mathrm{R}$ version 3.2.3 (Bloomfield, 2014): The number $\mathrm{Q}$ of adequate factorial axis for Principal Components Analysis (PCA) achievement was obtained according to the elbow criterion which enabled us to obtain the maximum of inertia kept with the maximum of factors. On the scree of eigenvalues, a drop was observed followed by a regular decrease. The axes before the offset represent the number of factorial axes to be used for the PCA

Biplot PCA-DA, correlation circle, contribution variables and discrimination trophic populations ${ }^{2}$ - R version 3.2.3 (Bloomfield, 2014): In the first place, a Principal Components Analysis (PCA) of raw data was carried out in the purpose of highlighting the raw Principal Components (PC) ${ }^{3}$. These were used to achieve a biplot combining the dispersion of PC (PCA) and that of individuals (Discriminant Analysis (DA)) in the adopted plans of the PCA, in order to see the degree of correlation between the variables and the level of involvement of the size factor to the morphological discrimination of trophic populations. Taking into account the correlation degree between the variables, the observed individuals' distribution was due only to the morphological differences directly related to the mean sizes of $T$. castaneum trophic populations. For this reason, after the logarithmic transformation of data, another PCA was generated to determine the $\mathrm{PC}_{\log / \mathrm{t}}$ ( $\mathrm{PC}$ of transformed variables-log). Another biplot was achieved with these $\mathrm{PC}_{\log / \mathrm{t}}$ retained in order to highlight the two trophic populations discrimination according to their specific form.

Size effect and logarithmic transformation of data (Darroch \& Mosimann, 1985): the size effect was manifested by the grouping of all PC in a single PCA plan for a given dimension (Santos, 2015 The principle of elimination is a logarithmic transformation that consists in putting all individuals back to the same size, in order to observe on the ACP only differences of form (Darroch \& Mosimann, 1985). The decrease in the size weight was reflected by a decrease of the overall discrimination between populations due to the discriminating decrease power of the dimension linked to size factor and the reduction of length between the barycenter of the two spectra of individuals (Santos, 2015)

Significance test of log-transformed mean differences- R version 3.2.3 (Bloomfield, 2014): The Shapiro-Wilk test is performed in advance to test on each log-transformed whether the sample follows a normal distribution or not. With non-significant P-values (P-value > 0.05), Gambia and Burkina samples follow a normal distribution according to the Log-transformed Lmt and Lta3. On the latter, the t.test (parametric) is performed to test the average differences between the trophic populations. With highly significant $\mathrm{P}$-values (P-value $<<<0.05)$, the other logtransforms showed that the sample does not follow a normal distribution. All things considered, the Mann-WhitneyWilcoxon test (non-parametric) is performed on these log-transformed to test the mean differences between the trophic populations. The threshold of significance $(\alpha)$ is set at 0.05 .

HAC - R version 3.2.3 (Bloomfield, 2014): Firstly, the agglomeration coefficient was calculated in order to see the structuring state 4 of the total population. The quality of distribution was measured by the Dunn

2 Group of individuals who have emerged on the same cereal.

${ }^{3}$ According to the elbow criterion, a variable is considered as PC only when it gives a meaning to the considered dimension. The contribution of the PC is always significant, meaning superior to the average contribution (CoNT_Aver $=1 / n$, with $n=$ number of variables used to perform the PCA).

5 Total population structured or not in two or more groups. 
Index (DI), which was calculated in each West African country for $\mathrm{k}=2$ and $\mathrm{K}=3$ (fixed distributions after analysis of inertia jumps of the elbow criterion) in order to see among these two distributions, the one which corresponded the most to the total population. The objective was to maximize the Dunn Index. Maximum DI maximized the interclass dissimilarity and minimized the intraclass dissimilarity. The average Index of Silhouette (IS) was calculated for each defined group in order to see the best grouped individuals of trophic populations. The Silhouette graph enabled us to identify the apriority bad grouped individuals and find the next inductive group within which they belonged.

\section{Results:-}

Choice of the number $\mathbf{Q}$ of factorial axes: with identical measurements in all individuals, variables such as length between the dorsally and ventrally eyes $(D y d, D y v)$ and the width of the femur of the third pair of legs (lf3) were eliminated from the analysis. The scree of eigenvalues had revealed a recess (elbow) after the first two axes, followed by a regular decrease from the third axes in all the sampled countries (Figure 2). This enabled us to retain the first two axes (the pins before the recess, $k=2$ ) for the PCA achievement.

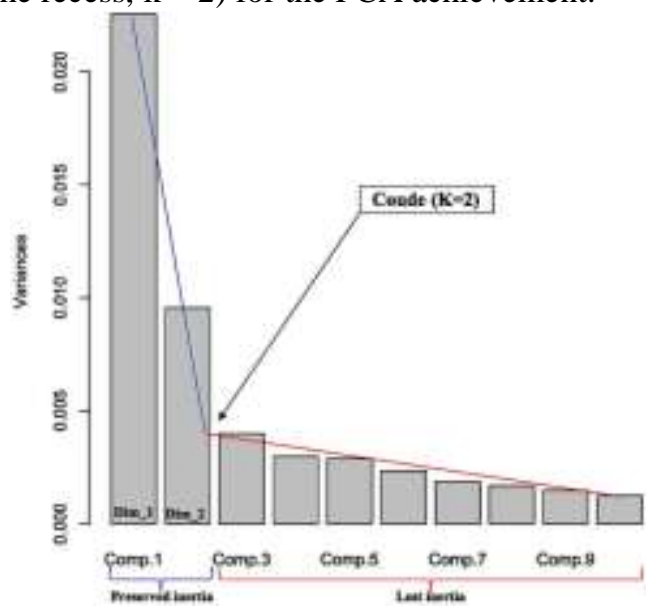

Figure 2:- Scree of Eigenvalues

Therefore the 1st PCA factorial plan (Dim_1, Dim_2) which held the maximum of inertia, gave the best quality of representation to explain the morphometric variability between trophic populations of T. castaneum in all sampled countries. After logarithmic transformation of data, the scree of eigenvalues retained this same typology in all West African countries.

Raw data: The $1^{\text {st }}$ discriminant analysis (DA) factorial plan revealed a morphometric difference between the trophic populations Millet and Rice of T. castaneum in all West African countries. Given the degree of correlation between the PC (grouping of PC (black) in a single PCA plan), this observed morphometric difference was strongly linked to the average size of trophic populations (Figure 3). This morphometric difference/size, in favor of individuals that emerged on the millet, was better explained in Senegal $\left(\mathrm{C}_{\text {ONT_global }}=70.2 \%\right)$ and in Gambia $\left(\mathrm{C}_{\text {ONT_global }}=71.5 \%\right)$. In Niger, R. of Guinea and Guinea Bissau, the two factorial dimensions explained 68.4\%, 60.9\% and 60.1\%, respectively the morphometric difference/size between these two populations and only $56.8 \%$ in Mali. The 1 st dimension (Dim_1), carrying the highest inertia, clearly discriminates these two populations in all the countries sampled except in Niger where the discrimination was made according to the 2nd dimension (Dim_2) (Figure 3). 


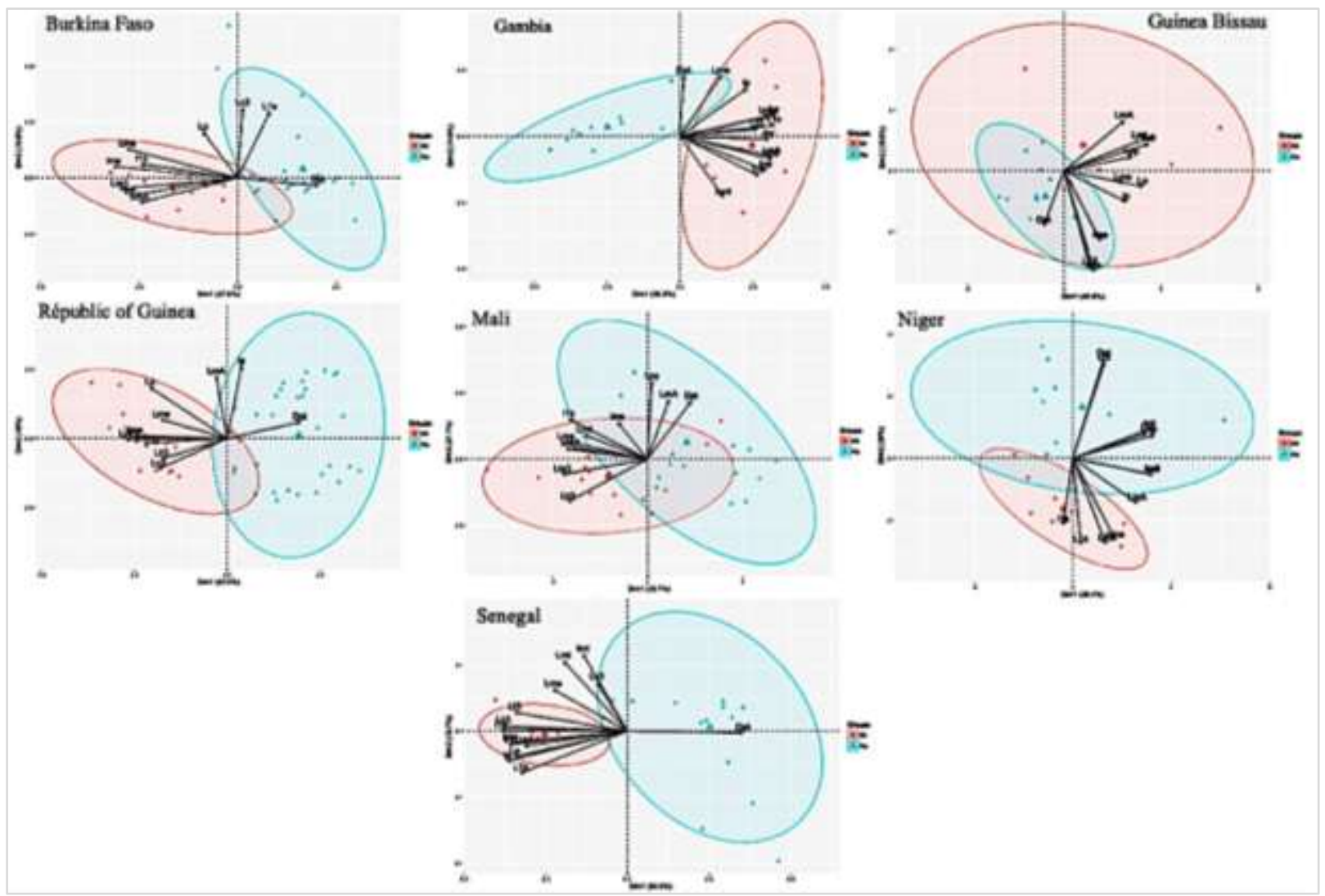

Figure 3:- Raw PC and individuals Biplot of trophic T. castaneum populations in West Africa

TRANSFORMED VARIABLES-LOG: Following the size effect elimination for the form effect, the plan formed by the first two dimensions always gives the best quality of representation and explains more the morphometric variability between the trophic populations of T. castaneum (Figure 4). In all the sampled countries, Dim_1 of the PCA, despite the decrease of its discriminate power, retained the higher inertia following the logarithmic transformation of the data and explained more the shape differences between these populations (Figure 4). Despite the overall inertias decline of all DA as a result of the elimination of size effect, this difference in form between these two populations had always been greater in Senegal $\left(\mathrm{F}_{\text {global }}=68.3 \%\right)$ and in the Gambia $\left(\mathrm{F}_{\text {global }}=61.4 \%\right)$. The DA had neighbors discriminating powers in Guinea Bissau $\left(\mathrm{F}_{\text {global }}=52.6 \%\right)$, in the Republic of Guinea $\left(\mathrm{F}_{\text {global }}=\right.$ $52.5 \%)$ and in Mali $\left(\mathrm{F}_{\text {global }}=52.5 \%\right)$. With an overall inertia of 58\%, the morphometric variability of trophic $T$. castaneum populations in Niger is now interpreted following the $1^{\text {st }}$ dimension after the logarithmic transformation of the data. The discriminating power of DA in Burkina Faso $\left(\mathrm{F}_{\text {global }}=56.3 \%\right)$ remained the same after the elimination of the size effect. That inertia variation of the PCA dimensions following the transformation of the data was due to a loss or gain of inertia of the two PCA dimensions resulting respectively in a significant 5 decrease or an increase in the PC contribution to the construction of a given dimension (Figure 4). In all West African countries, almost all log-t were $\mathrm{PC}_{\log / \mathrm{t}}($ Figure 4$) . \mathrm{All} \mathrm{CP}_{\log / \mathrm{t}}$ clearly discriminated the two trophic populations according to their specific form.

\footnotetext{
${ }^{5}$ The variation of the variable's contribution is significant if it changes the significance of the variable's contribution. Increase: Cont < Cont_Avg to Cont > Cont_Avg after processing or decrease: Cont > Cont_Avg to Cont < Cont_Avg.
} 


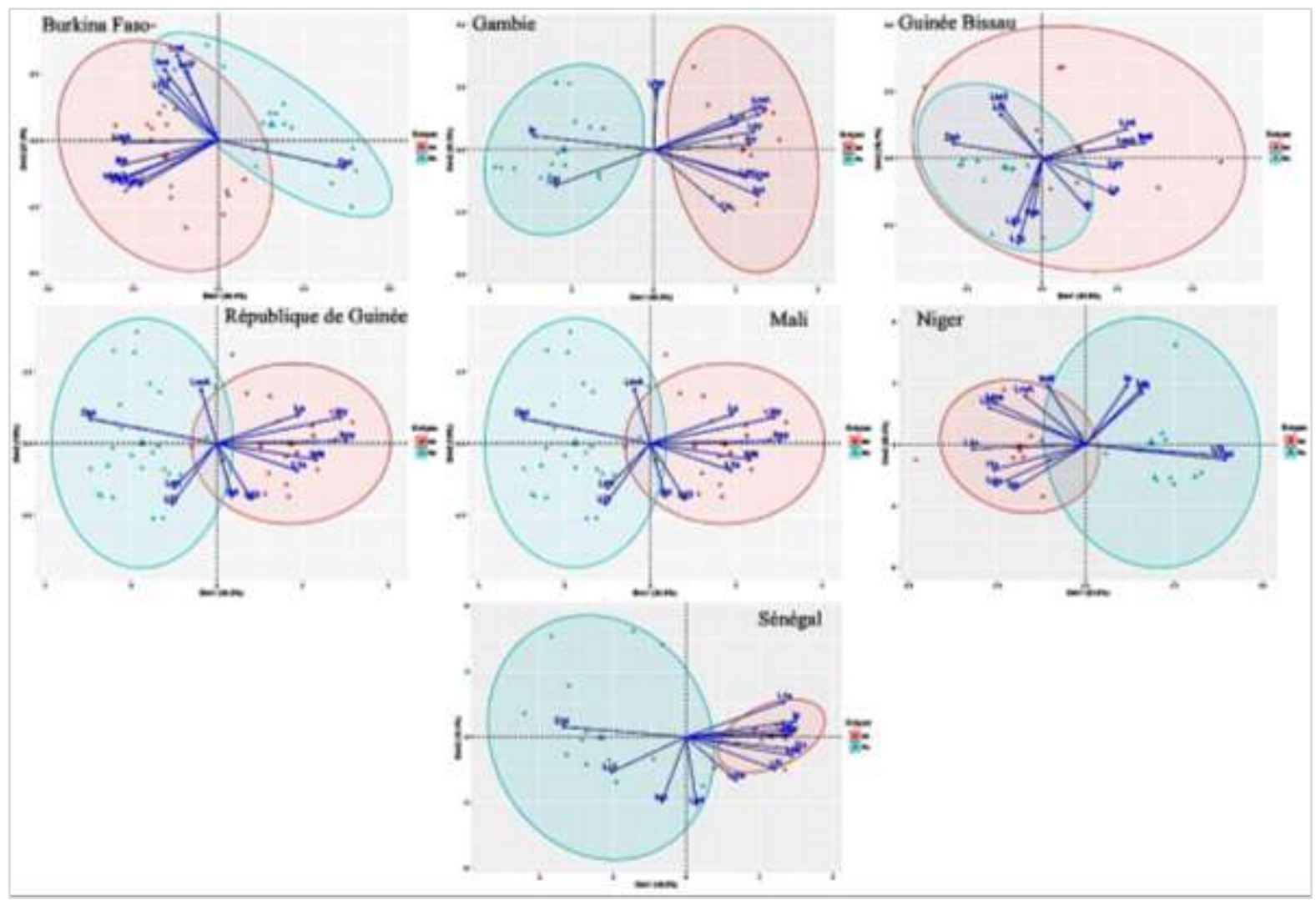

Figure 4:- $\mathrm{PC}_{\mathrm{log} / \mathrm{t}}$ and individuals Biplot of trophic T. castaneum populations in West Africa

Significance test of log-transformed (Log-t) means differences and features morphological of each population trophic: the trophic $T$. castaneum populations of Millet and Rice were morphologically differentiated in all sampled west African countries (Tableau 3). This morphological dissimilarity varied from one country to another and was more important than the number of log-t which revealed a difference of significant medium sized between these two populations was high. In particular, this morphological dissimilarity was more important in Senegal (14 log-t / 16 which differentiated the two trophic populations), Guinea Bissau (13 log-t / 16), Gambia (12 log-t / 16) and in Niger and Republic of Guinea (10 log-t / 16) and less important in Burkina Faso (9 log-t / 16) and Mali (8 log-t / 16) (Tableau 3). Taking into account the significance of Differences in transformed variables-log averages observed between the two trophic T. Castaneum populations, it became possible to determine the morphological feature of each of them. Then, the two trophic T. castaneum populations had different morphological features in all West African countries (Tableau 3).

Tableau 3:- Average \pm standard deviation of log-transformed for each trophic population and significance test of means differences between populations.

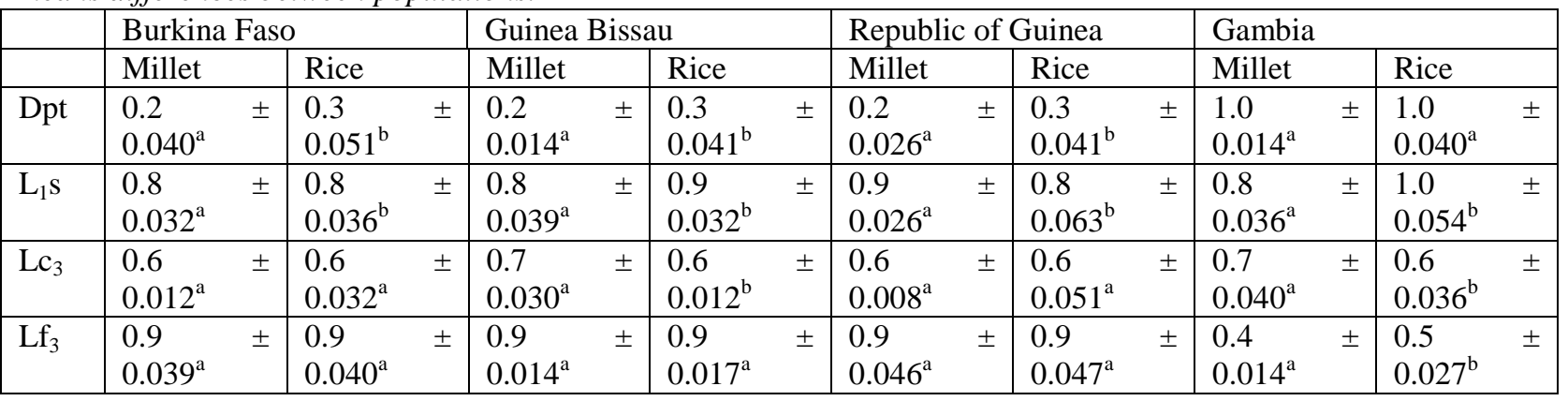




\begin{tabular}{|c|c|c|c|c|c|c|c|c|c|c|c|c|c|c|c|c|}
\hline Lma & $\begin{array}{l}0.9 \\
0.012^{\mathrm{a}} \\
\end{array}$ & \pm & $\begin{array}{l}0.9 \\
0.048^{b}\end{array}$ & \pm & $\begin{array}{l}1.0 \\
0.026^{\mathrm{a}} \\
\end{array}$ & \pm & $\begin{array}{l}0.9 \\
0.050^{\mathrm{b}}\end{array}$ & \pm & $\begin{array}{l}0.9 \\
0.050^{\mathrm{a}} \\
\end{array}$ & \pm & $\begin{array}{l}1.0 \\
0.047^{\mathrm{b}}\end{array}$ & \pm & $\begin{array}{l}1.1 \\
0.040^{\mathrm{a}} \\
\end{array}$ & \pm & $\begin{array}{l}1.0 \\
0.041^{b}\end{array}$ & \\
\hline Lme & $\begin{array}{l}2.5 \\
0.102^{\mathrm{a}}\end{array}$ & \pm & $\begin{array}{l}2.4 \\
0.073^{b}\end{array}$ & \pm & $\begin{array}{l}2.6 \\
0.043^{\mathrm{a}}\end{array}$ & \pm & $\begin{array}{l}2.5 \\
0.097^{\mathrm{b}}\end{array}$ & \pm & $\begin{array}{l}2.5 \\
0.095^{\mathrm{a}}\end{array}$ & \pm & $\begin{array}{l}2.5 \\
0.094^{\mathrm{a}}\end{array}$ & \pm & $\begin{array}{l}2.5 \\
0.122^{\mathrm{a}}\end{array}$ & \pm & $\begin{array}{l}2.6 \\
0.068^{\mathrm{a}}\end{array}$ & \pm \\
\hline Lmt & $\begin{array}{l}1.0 \\
0.012^{\mathrm{a}}\end{array}$ & \pm & $\begin{array}{l}1.0 \\
0.007^{\mathrm{a}}\end{array}$ & \pm & $\begin{array}{l}1.1 \\
0.026^{\mathrm{a}}\end{array}$ & \pm & $\begin{array}{l}1.0 \\
0.012^{\mathrm{b}}\end{array}$ & \pm & $\begin{array}{l}1.0 \\
0.054^{\mathrm{a}}\end{array}$ & \pm & $\begin{array}{l}1.1 \\
0.042^{b}\end{array}$ & \pm & $\begin{array}{l}1.0 \\
0.052^{\mathrm{a}}\end{array}$ & \pm & $\begin{array}{l}0.9 \\
0.028^{b}\end{array}$ & \pm \\
\hline Lp & $\begin{array}{l}1.0 \\
0.018^{\mathrm{a}}\end{array}$ & \pm & $\begin{array}{l}1.0 \\
0.026^{\mathrm{a}}\end{array}$ & \pm & $\begin{array}{l}1.1 \\
0.036^{\mathrm{a}}\end{array}$ & \pm & $\begin{array}{l}1.0 \\
0.033^{b}\end{array}$ & \pm & $\begin{array}{l}1.1 \\
0.033^{\mathrm{a}}\end{array}$ & \pm & $\begin{array}{l}1.0 \\
0.046^{\mathrm{a}}\end{array}$ & \pm & $\begin{array}{l}1.2 \\
0.040^{\mathrm{a}}\end{array}$ & \pm & $\begin{array}{l}1.1 \\
0.033^{b}\end{array}$ & \pm \\
\hline Lpy & $\begin{array}{l}0.6 \\
0.063^{\mathrm{a}}\end{array}$ & \pm & $\begin{array}{l}0.6 \\
0.046^{\mathrm{a}}\end{array}$ & \pm & $\begin{array}{l}0.6 \\
0.056^{\mathrm{a}}\end{array}$ & \pm & $\begin{array}{l}0.5 \\
0.031^{b}\end{array}$ & \pm & $\begin{array}{l}0.6 \\
0.043^{\mathrm{a}}\end{array}$ & \pm & $\begin{array}{l}0.5 \\
0.014^{b}\end{array}$ & \pm & $\begin{array}{l}0.6 \\
0.044^{\mathrm{a}}\end{array}$ & \pm & $\begin{array}{l}0.5 \\
0.024^{b}\end{array}$ & \pm \\
\hline $\mathrm{Lta}_{3}$ & $\begin{array}{l}0.6 \\
0.022^{\mathrm{a}} \\
\end{array}$ & \pm & $\begin{array}{l}0.6 \\
0.036^{\mathrm{b}}\end{array}$ & \pm & $\begin{array}{l}0.5 \\
0.014^{\mathrm{a}}\end{array}$ & \pm & $\begin{array}{l}0.5 \\
0.022^{\mathrm{a}}\end{array}$ & \pm & $\begin{array}{l}0.5 \\
0.008^{\mathrm{a}}\end{array}$ & \pm & $\begin{array}{l}0.6 \\
0.041^{b}\end{array}$ & \pm & $\begin{array}{l}0.6 \\
0.021^{\mathrm{a}}\end{array}$ & \pm & $\begin{array}{l}0.6 \\
0.041^{\mathrm{a}}\end{array}$ & \pm \\
\hline $\mathrm{Lti}_{3}$ & $\begin{array}{l}0.9 \\
0.048^{\mathrm{a}} \\
\end{array}$ & \pm & $\begin{array}{l}0.9 \\
0.027^{\mathrm{b}} \\
\end{array}$ & \pm & $\begin{array}{l}0.9 \\
0.037^{\mathrm{a}} \\
\end{array}$ & \pm & $\begin{array}{l}1.0 \\
0.012^{\mathrm{b}}\end{array}$ & \pm & $\begin{array}{l}0.9 \\
0.029^{a} \\
\end{array}$ & \pm & $\begin{array}{l}0.9 \\
0.049^{\mathrm{a}}\end{array}$ & \pm & $\begin{array}{l}0.9 \\
0.049^{\mathrm{a}} \\
\end{array}$ & \pm & $\begin{array}{l}0.9 \\
0.051^{\mathrm{a}} \\
\end{array}$ & \pm \\
\hline$l_{1} \mathrm{~S}$ & $\begin{array}{l}1.2 \\
0.045^{\mathrm{a}}\end{array}$ & \pm & $\begin{array}{l}1.1 \\
0.019^{b}\end{array}$ & \pm & $\begin{array}{l}1.2 \\
0.036^{\mathrm{a}}\end{array}$ & \pm & $\begin{array}{l}1.1 \pm \\
0.043^{b}\end{array}$ & & $\begin{array}{l}1.1 \\
0.043^{\mathrm{a}}\end{array}$ & \pm & $\begin{array}{l}1.2 \\
0.036^{b}\end{array}$ & \pm & $\begin{array}{l}1.3 \\
0.042^{\mathrm{a}}\end{array}$ & \pm & $\begin{array}{l}1.2 \\
0.029^{b}\end{array}$ & \pm \\
\hline lme & $\begin{array}{l}1.0 \\
0.033^{\mathrm{a}}\end{array}$ & \pm & $\begin{array}{l}0.9 \\
0.033^{b}\end{array}$ & \pm & $\begin{array}{l}1.0 \\
0.043^{\mathrm{a}}\end{array}$ & \pm & $\begin{array}{l}1.1 \\
0.038^{b}\end{array}$ & \pm & $\begin{array}{l}1.0 \\
0.045^{\mathrm{a}}\end{array}$ & \pm & $\begin{array}{l}0.9 \\
0.014^{b}\end{array}$ & \pm & $\begin{array}{l}1.1 \\
0.014^{\mathrm{a}}\end{array}$ & \pm & $\begin{array}{l}1.0 \\
0.027^{b}\end{array}$ & \pm \\
\hline $\operatorname{lmt}$ & $\begin{array}{l}0.9 \\
0.012^{\mathrm{a}}\end{array}$ & \pm & $\begin{array}{l}0.9 \\
0.019^{\mathrm{a}}\end{array}$ & \pm & $\begin{array}{l}1.0 \\
0.030^{\mathrm{a}}\end{array}$ & \pm & $\begin{array}{l}0.9 \\
0.012^{b}\end{array}$ & \pm & $\begin{array}{l}0.9 \\
0.008^{\mathrm{a}}\end{array}$ & \pm & $\begin{array}{l}0.9 \\
0.047^{\mathrm{a}}\end{array}$ & \pm & $\begin{array}{l}1.0 \\
0.014^{\mathrm{a}}\end{array}$ & \pm & $\begin{array}{l}0.9 \\
0.029^{b}\end{array}$ & \pm \\
\hline $\mathrm{lp}$ & $\begin{array}{l}1.2 \\
0.042^{\mathrm{a}} \\
\end{array}$ & \pm & $\begin{array}{l}1.1 \\
0.032^{\mathrm{a}} \\
\end{array}$ & \pm & $\begin{array}{l}1.2 \\
0.039^{\mathrm{a}} \\
\end{array}$ & \pm & $\begin{array}{l}1.1 \\
0.034^{\mathrm{b}} \\
\end{array}$ & \pm & $\begin{array}{l}1.1 \\
0.037^{\mathrm{a}}\end{array}$ & \pm & $\begin{array}{l}1.2 \\
0.047^{\mathrm{b}}\end{array}$ & \pm & $\begin{array}{l}0.3 \\
0.030^{\mathrm{a}} \\
\end{array}$ & \pm & $\begin{array}{l}0.4 \\
0.032^{\mathrm{b}} \\
\end{array}$ & \pm \\
\hline \multirow[t]{3}{*}{ lpy } & $\begin{array}{l}1.0 \\
0.047^{\mathrm{a}}\end{array}$ & \pm & $\begin{array}{l}0.9 \\
0.007^{\mathrm{b}}\end{array}$ & \pm & $\begin{array}{l}1.0 \\
0.047^{\mathrm{a}}\end{array}$ & \pm & $\begin{array}{l}1.0 \\
0.046^{\mathrm{a}} \\
\end{array}$ & \pm & $\begin{array}{l}1.0 \\
0.036^{\mathrm{a}}\end{array}$ & \pm & $\begin{array}{l}0.9 \\
0.047^{b}\end{array}$ & \pm & $\begin{array}{l}1.1 \\
0.037^{\mathrm{a}}\end{array}$ & \pm & $\begin{array}{l}1.0 \\
0.034^{\mathrm{b}}\end{array}$ & \pm \\
\hline & \multicolumn{4}{|l|}{ Mali } & \multicolumn{4}{|l|}{ Niger } & \multicolumn{4}{|l|}{ Senegal } & & & & \\
\hline & Millet & & Rice & & Millet & & Rice & & Millet & & Rice & & & & & \\
\hline Dpt & $\begin{array}{l}0.2 \\
0.025^{\mathrm{a}} \\
\end{array}$ & \pm & $\begin{array}{l}0.3 \\
0.039^{\mathrm{b}} \\
\end{array}$ & & $\begin{array}{l}0.2 \\
0.010^{\mathrm{a}}\end{array}$ & \pm & $\begin{array}{l}0.3 \\
0.036^{\mathrm{b}}\end{array}$ & \pm & $\begin{array}{l}0.2 \\
0.006^{\mathrm{a}}\end{array}$ & \pm & $\begin{array}{l}0.3 \\
0.033^{b}\end{array}$ & \pm & & & & \\
\hline $\mathrm{L}_{1} \mathrm{~S}$ & $\begin{array}{l}0.9 \\
0.007^{\mathrm{a}}\end{array}$ & \pm & $\begin{array}{l}0.8 \\
0.044^{b}\end{array}$ & \pm & $\begin{array}{l}0.8 \\
0.030^{\mathrm{a}}\end{array}$ & \pm & $\begin{array}{l}0.7 \\
0.038^{\mathrm{b}}\end{array}$ & \pm & $\begin{array}{l}0.8 \\
0.021^{\mathrm{a}}\end{array}$ & \pm & $\begin{array}{l}0.7 \\
0.069^{b}\end{array}$ & \pm & & & & \\
\hline $\mathrm{Lc}_{3}$ & $\begin{array}{l}0.6 \\
0.007^{\mathrm{a}}\end{array}$ & \pm & $\begin{array}{l}0.7 \\
0.028^{\mathrm{a}}\end{array}$ & & $\begin{array}{l}0.7 \\
0.031^{\mathrm{a}}\end{array}$ & \pm & $\begin{array}{l}0.7 \\
0.026^{\mathrm{a}}\end{array}$ & \pm & $\begin{array}{l}0.6 \\
0.006^{\mathrm{a}}\end{array}$ & \pm & $\begin{array}{l}0.7 \\
0.019^{b}\end{array}$ & \pm & & & & \\
\hline $\mathrm{Lf}_{3}$ & $\begin{array}{l}0.9 \\
0.047^{\mathrm{a}}\end{array}$ & \pm & $\begin{array}{l}1.0 \\
0.021^{b}\end{array}$ & \pm & $\begin{array}{l}0.8 \\
0.010^{\mathrm{a}}\end{array}$ & \pm & $\begin{array}{l}0.9 \\
0.036^{b}\end{array}$ & \pm & $\begin{array}{l}0.9 \\
0.006^{\mathrm{a}}\end{array}$ & \pm & $\begin{array}{l}0.8 \\
0.045^{\mathrm{b}}\end{array}$ & \pm & & & & \\
\hline Lma & $\begin{array}{l}0.9 \\
0.047^{\mathrm{a}}\end{array}$ & \pm & $\begin{array}{l}0.9 \\
0.047^{\mathrm{a}}\end{array}$ & \pm & $\begin{array}{l}0.9 \\
0.044^{\mathrm{a}}\end{array}$ & \pm & $\begin{array}{l}0.8 \\
0.030^{b}\end{array}$ & \pm & $\begin{array}{l}0.9 \\
0.049^{\mathrm{a}}\end{array}$ & \pm & $\begin{array}{l}0.8 \\
0.019^{b}\end{array}$ & \pm & & & & \\
\hline Lme & $\begin{array}{l}2.6 \\
0.097^{\mathrm{a}} \\
\end{array}$ & \pm & $\begin{array}{l}2.5 \\
0.091^{\mathrm{a}} \\
\end{array}$ & \pm & $\begin{array}{l}2.6 \\
0.063^{\mathrm{a}} \\
\end{array}$ & \pm & $\begin{array}{l}2.5 \\
0.080^{b} \\
\end{array}$ & \pm & $\begin{array}{l}2.5 \\
0.117^{\mathrm{a}}\end{array}$ & \pm & $\begin{array}{l}2.5 \\
0.104^{\mathrm{a}} \\
\end{array}$ & \pm & & & & \\
\hline Lmt & $\begin{array}{l}1.0 \\
0.051^{\mathrm{a}}\end{array}$ & \pm & $\begin{array}{l}1.0 \\
0.040^{\mathrm{a}}\end{array}$ & \pm & $\begin{array}{l}1.0 \\
0.055^{\mathrm{a}}\end{array}$ & \pm & $\begin{array}{l}1.0 \\
0.035^{\mathrm{a}}\end{array}$ & \pm & $\begin{array}{l}1.0 \\
0.023^{\mathrm{a}}\end{array}$ & \pm & $\begin{array}{l}1.0 \\
0.044^{\mathrm{a}}\end{array}$ & \pm & & & & \\
\hline Lp & $\begin{array}{l}1.0 \\
0.007^{\mathrm{a}} \\
\end{array}$ & \pm & $\begin{array}{l}1.0 \\
0.038^{\mathrm{a}} \\
\end{array}$ & \pm & $\begin{array}{l}1.0 \\
0.037^{\mathrm{a}} \\
\end{array}$ & \pm & $\begin{array}{l}1.1 \\
0.026^{\mathrm{b}}\end{array}$ & \pm & $\begin{array}{l}1.0 \\
0.006^{\mathrm{a}} \\
\end{array}$ & \pm & $\begin{array}{l}0.9 \\
0.044^{b} \\
\end{array}$ & \pm & & & & \\
\hline Lpy & $\begin{array}{l}0.5 \\
0.032^{\mathrm{a}}\end{array}$ & \pm & $\begin{array}{l}0.6 \\
0.035^{b}\end{array}$ & & $\begin{array}{l}0.6 \\
0.019^{\mathrm{a}}\end{array}$ & \pm & $\begin{array}{l}0.5 \\
0.018^{\mathrm{a}}\end{array}$ & \pm & $\begin{array}{l}0.7 \\
0.021^{\mathrm{a}}\end{array}$ & \pm & $\begin{array}{l}0.6 \\
0.098^{b}\end{array}$ & \pm & & & & \\
\hline $\mathrm{Lta}_{3}$ & $\begin{array}{l}0.6 \\
0.057^{\mathrm{a}}\end{array}$ & \pm & $\begin{array}{l}0.5 \\
0.035^{\mathrm{b}}\end{array}$ & & $\begin{array}{l}0.6 \\
0.041^{\mathrm{a}}\end{array}$ & \pm & $\begin{array}{l}0.5 \\
0.046^{b}\end{array}$ & \pm & $\begin{array}{l}0.7 \\
0.032^{\mathrm{a}}\end{array}$ & \pm & $\begin{array}{l}0.6 \\
0.041^{b}\end{array}$ & \pm & & & & \\
\hline $\mathrm{Lti}_{3}$ & $\begin{array}{l}0.9 \\
0.030^{\mathrm{a}}\end{array}$ & \pm & $\begin{array}{l}0.8 \\
0.017^{b}\end{array}$ & & $\begin{array}{l}1.0 \\
0.029^{\mathrm{a}}\end{array}$ & \pm & $\begin{array}{l}0.9 \\
0.054^{\mathrm{b}}\end{array}$ & \pm & $\begin{array}{l}0.9 \\
0.006^{\mathrm{a}}\end{array}$ & \pm & $\begin{array}{l}0.8 \\
0.038^{b}\end{array}$ & \pm & & & & \\
\hline$l_{1} \mathrm{~S}$ & $\begin{array}{l}1.2 \\
0.045^{\mathrm{a}} \\
\end{array}$ & \pm & $\begin{array}{l}1.1 \\
0.038^{\mathrm{b}} \\
\end{array}$ & \pm & $\begin{array}{l}1.2 \\
0.050^{\mathrm{a}} \\
\end{array}$ & \pm & $\begin{array}{l}1.1 \\
0.018^{b}\end{array}$ & \pm & $\begin{array}{l}1.2 \\
0.021^{\mathrm{a}}\end{array}$ & \pm & $\begin{array}{l}1.1 \\
0.034^{b}\end{array}$ & \pm & & & & \\
\hline lme & $\begin{array}{l}1.0 \\
0.050^{\mathrm{a}} \\
\end{array}$ & \pm & $\begin{array}{l}1.0 \\
0.046^{\mathrm{a}} \\
\end{array}$ & \pm & $\begin{array}{l}1.0 \\
0.032^{\mathrm{a}} \\
\end{array}$ & \pm & $\begin{array}{l}1.0 \\
0.026^{\mathrm{a}} \\
\end{array}$ & \pm & $\begin{array}{l}1.0 \\
0.036^{\mathrm{a}} \\
\end{array}$ & \pm & $\begin{array}{l}0.9 \\
0.013^{b}\end{array}$ & \pm & & & & \\
\hline $\operatorname{lmt}$ & $\begin{array}{l}1.0 \\
0.035^{\mathrm{a}} \\
\end{array}$ & \pm & $\begin{array}{l}0.9 \\
0.039^{\mathrm{b}} \\
\end{array}$ & \pm & $\begin{array}{l}9.0 \\
0.010^{\mathrm{a}} \\
\end{array}$ & \pm & $\begin{array}{l}1.0 \\
0.030^{\mathrm{b}}\end{array}$ & \pm & $\begin{array}{l}0.9 \\
0.006^{\mathrm{a}} \\
\end{array}$ & \pm & $\begin{array}{l}1.0 \\
0.038^{\mathrm{b}}\end{array}$ & \pm & & & & \\
\hline $1 p$ & & \pm & 1.1 & \pm & 1.2 & \pm & 1.2 & \pm & 1.2 & \pm & 1.1 & \pm & & & & \\
\hline
\end{tabular}




\begin{tabular}{|l|ll|ll|ll|ll|ll|l|}
\hline & $0.047^{\mathrm{a}}$ & & $0.055^{\mathrm{a}}$ & & $0.010^{\mathrm{a}}$ & & $0.026^{\mathrm{a}}$ & & $0.006^{\mathrm{a}}$ & & $0.027^{\mathrm{b}}$ \\
\hline lpy & 0.9 & \pm & 1.0 & \pm & 1.0 & \pm & 0.9 & \pm & 1.0 & \pm & 0.9 \\
& $0.007^{\mathrm{a}}$ & & $0.041^{\mathrm{a}}$ & & $0.037^{\mathrm{a}}$ & & $0.018^{\mathrm{b}}$ & & $0.033^{\mathrm{a}}$ & & $0.013^{\mathrm{b}}$ \\
\hline
\end{tabular}

The letters $(a, b)$ denote significant morphological differences between populations for the log-transformed considered at the significant level of 5\%. Burkina Faso, Guinea Bissau, Republic Guinea, Gambia, Mali, Niger and Senegal represent the sample geographical sites.

\section{Ascending Hierarchical Classification (AHC) of trophic T. castaneum populations:-}

-Agglomeration Coefficient (AC): More the agglomeration Coefficient is close to 1 ( $\mathrm{AC} \geq 0.5$ ), more the individuals who composed the population were highly structured in several groups. Then, we notice values of the AC $(0,6537 \leq$ $\mathrm{CA} \leq 0,9504 \mathrm{AC}$ ) that the individuals of each populations of West African countries were highly structured in several morphological groups (Figure 5).

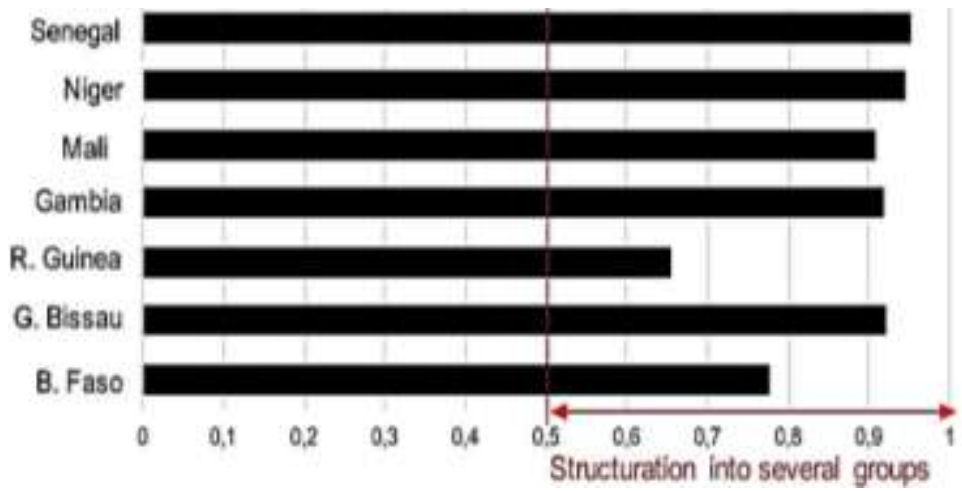

Figure 5:- Agglomeration Coefficient

With Dunn slightly higher Indexes (DI) to $\mathrm{K}=2$, individuals of the two trophic populations, were grouped into two morphological clusters in the Gambia (DI =0.4130), Mali (DI =0.4919), in Niger (DI =0.4641) and Senegal (DI = 0.4384) (Table 4). To K = 3, the Dunn Index had increased in Guinea Bissau (DI-2 = 0.3752; DI-3 = 0.4563), and the Gambia (DI-2 =0.4130; DI-3 = 0.5128), revealing a better classification of individuals of their populations in 3 clusters. Then the interclass dissimilarity was maximum and the intraclass dissimilarity was minimal for $\mathrm{k}=2$ in Burkina Faso, Republic of Guinea, Senegal, Mali and Niger, and for $\mathrm{k}=3$ in Guinea Bissau and Gambia (Table 4).

Table 4:- Distribution of trophic millet and rice populations in the defined morphological groups

\begin{tabular}{|l|l|l|l|l|l|l|l|l|}
\hline \multicolumn{2}{|l|}{ Quality Index } & B. Faso & G. Bissau & R. Guinea & Gambia & Mali & Niger & Senegal \\
\hline \multirow{2}{*}{$\begin{array}{l}\text { Dunn } \\
\text { Index }\end{array}$} & $\mathrm{K}=2$ & 0,3544 & 0,3752 & 0,3729 & 0,4130 & 0,4919 & 0,4641 & 0,4384 \\
\cline { 2 - 9 } & $\mathrm{K}=3$ & 0.3808 & 0.4563 & 0.3729 & 0.5128 & 0.3935 & 0.4105 & 0.3479 \\
\hline
\end{tabular}

Dendrogram - Then two classes $(\mathrm{k}=2)$ were deducted to draw the dendrogram of the two trophic $T$. castaneum populations in Burkina Faso, Republic of Guinea, Mali, Niger and Senegal and three classes $(\mathrm{k}=3)$ in Gambia and Guinea Bissau, in order to see in each West African country, the degree of morphological dissimilarity between the individuals of these two populations according to their distribution in these two defined classes (Figure 6). In the Gambia and in Guinea Bissau, morphogroups _2 and _3 are some sort of sub-distinct classes coming from the same morphological class (Figure 6). 


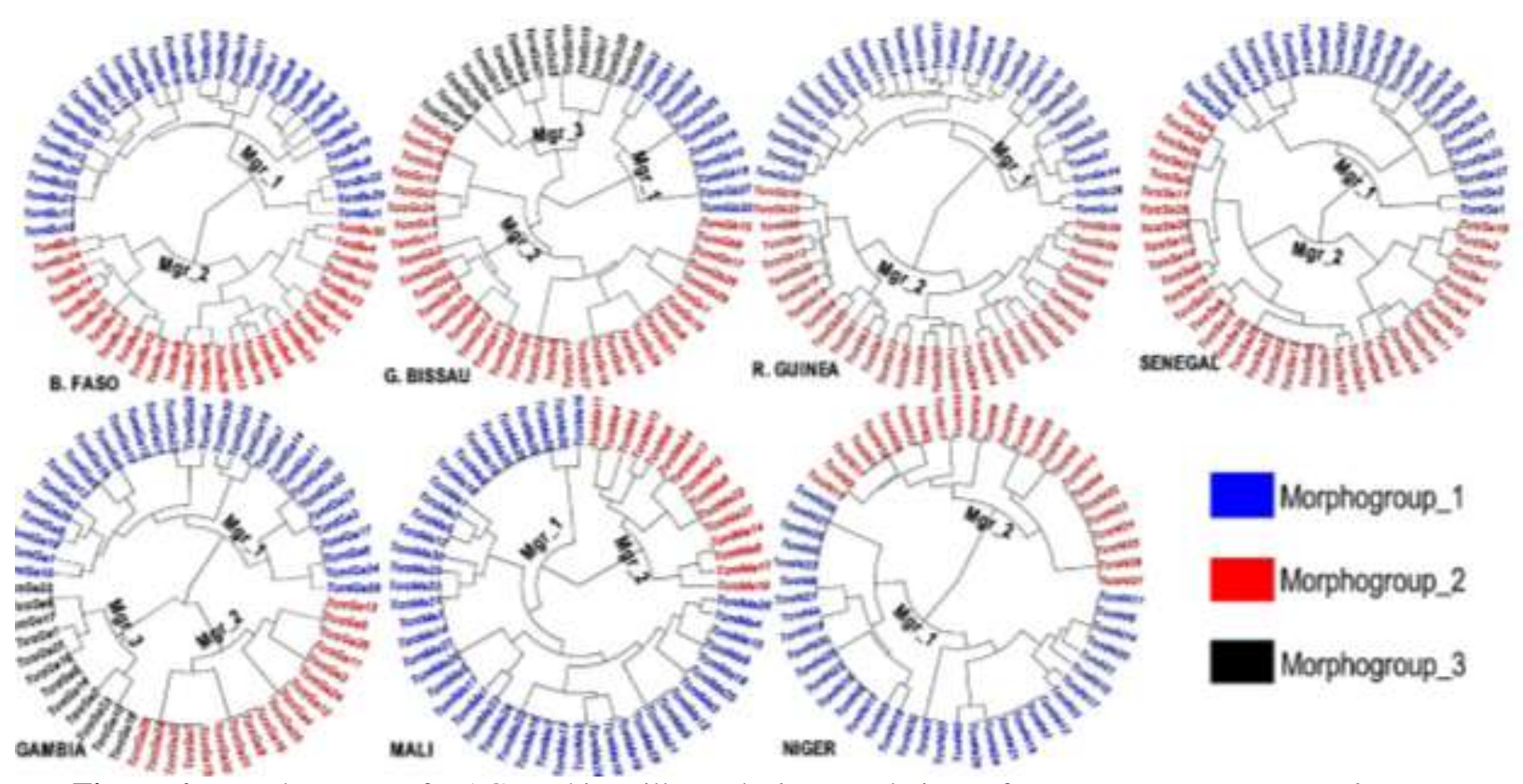

Figure 6:- Dendrograms of HAC trophic Millet and Rice populations of T. castaneum. Mgr: morphogroup.

In all West African countries, the morphogroup _ 1 was strongly dominated by individuals of the trophic millet population and morphogroups _2 and 3 were mainly formed by those of the rice trophic population. Then, the morphogroups _1 and _2 explained respectively the morphology of Millet and rice trophic populations in Burkina Faso, Gambia, Republic of Guinea, Niger and Senegal (Table 5). On the contrary, single morphogroup explained better the morphology of the two trophic populations in Mali (morphogroup_1, with 75\% of the individuals in the total population). In Gambia and Guinea Bissau, the trophic rice population was characterized by two distinct morphologies. The population of millet was morphologically more heterogeneous in Guinea Bissau where the three morphologies were observed in this population (Table 5).

Table 5:- Individuals distribution of trophic millet and rice populations in the defined morphological groups

\begin{tabular}{|c|c|c|c|c|c|c|c|c|c|c|}
\hline & \multicolumn{2}{|c|}{ B. Faso } & \multicolumn{2}{|l|}{ Mali } & \multicolumn{2}{|c|}{ R. Guinea } & \multicolumn{2}{|c|}{ Senegal } & \multicolumn{2}{|l|}{ Niger } \\
\hline$\%$ & Mgr_1 & MGr_2 & Mgr_1 & Mgr_2 & Mgr_1 & Mgr_2 & Mgr_1 & Mgr_2 & Mgr_1 & Mgr_2 \\
\hline Millet & 90 & 10 & 60 & 40 & 97 & 03 & 80 & 20 & 100 & 00 \\
\hline Rice & 17 & 83 & 90 & 10 & 00 & 100 & 00 & 100 & 17 & 83 \\
\hline Total & 53.3 & 46.7 & 75.0 & 25.0 & 48.3 & 51.7 & 40.0 & 60.0 & 58.3 & 41.7 \\
\hline & \multicolumn{3}{|c|}{ G. Bissau } & \multicolumn{3}{|l|}{ Gambia } & & & & \\
\hline$\%$ & Mgr_1 & Mgr_2 & Mgr_3 & Mgr_1 & Mgr_2 & Mgr_3 & & & & \\
\hline Millet & 37 & 46 & 17 & 100 & 00 & 00 & & & & \\
\hline Rice & 00 & 70 & 30 & 00 & 60 & 40 & & & & \\
\hline Total & 18.3 & 58.4 & 23.3 & 50.0 & 30.0 & 20.0 & & & & \\
\hline
\end{tabular}

In Burkina Faso, Republic of Guinea, Mali, Niger and Gambia, the morphogroup_1, composed in majority of individuals of the trophic millet population, had the lowest intragroup inertia compared to other morphogroups, just as the morphogroup_2 in Senegal and the morphogroup_3 in Guinea Bissau composed mainly of individuals from the trophic rice population (Table 6).

The largest intergroups inertia were noted between the morphogroups_1 and _2 in the Republic of Guinea (0.0615) and in Senegal (0.0567), morphogroups composed in majority of individuals of different trophic populations (Table 6). In Guinea Bissau and in the Gambia, the largest intergroups inertia were respectively noted between the morphogroups _ 1 and_3 and morphoroups _ 1 and _2. The lowest intergroups inertia were registered between morphogroups of individuals of the same trophic population (between morphogroups_2 and _3 in Guinea Bissau and the Gambia) (Table 6). 
Table 6: Ascending Hierarchical Classification Quality Indexes of T. castaneum individuals of trophic populations in each West African country. $\mathbf{I}_{\mathbf{a v g}}$ : average index

\begin{tabular}{|c|c|c|c|c|c|c|c|c|}
\hline \multirow{2}{*}{\multicolumn{2}{|c|}{ Quality indexes }} & \multicolumn{5}{|l|}{$\mathrm{K}=2$} & \multicolumn{2}{|l|}{$\mathrm{K}=3$} \\
\hline & & B. Faso & R. Guinea & Mali & Niger & Senegal & G. Bissau & Gambia \\
\hline \multirow{3}{*}{$\begin{array}{l}\text { Intragroup } \\
\text { inertia }\end{array}$} & Mgr_1 & 0.0195 & 0.0269 & 0.0260 & 0.0145 & 0.0311 & 0.0169 & 0.0111 \\
\hline & Mgr_2 & 0.0270 & 0.0365 & 0.0265 & 0.0259 & 0.0291 & 0.0174 & 0.0213 \\
\hline & Mgr_3 & --------- & ---------- & ----------- & ---------- & - & 0.0131 & 0.0236 \\
\hline \multirow{3}{*}{$\begin{array}{l}\text { Intergroup } \\
\text { inertia }\end{array}$} & Mgr_1 - 2 & 0.0268 & 0.0615 & 0.0303 & 0.0286 & 0.0567 & 0.0071 & 0.0312 \\
\hline & Mgr_1 - 3 & ---------- & ---------- & ---------- & ---------- & ---------- & 0.0423 & 0.0284 \\
\hline & Mgr_2-3 & - & - & ----------- & ---------- & - & 0.0046 & 0.0286 \\
\hline \multicolumn{2}{|c|}{$\mathrm{I}_{\mathrm{avg}}$ of silhouette } & 0.28 & 0.29 & 0.30 & 0.32 & 0.36 & 0.26 & 0.33 \\
\hline
\end{tabular}

Index and graph Silhouette - The widths of Silhouette revealed a reasonable structure of the retained partition of $T$. castaneum trophic populations $\left.\left.\left(\mathrm{I}_{\text {avg }} \in\right] 0.31,0.50\right]\right)$ in Niger, Senegal and Gambia and a weak structure $\left(\mathrm{I}_{\text {avg }} \in\right] 0$, 0.30]) in Burkina Faso, Republic of Guinea, Mali and Guinea Bissau. Individuals of millet and rice trophic populations were better classified in their morphological group specific to Senegal $\left(I_{\text {avg }} S=0.36\right)$, Gambia $\left(I_{\text {avg }} S=\right.$ 0.33 ) and Niger $\left(\mathrm{I}_{\text {avg }} \mathrm{S}=0.32\right.$ ) (Figure 7). Priori individuals of the morphogroup_1 were better classified posteriori for most of the West African countries including in Burkina Faso $($ SI1 = 0.35), Niger $($ SI1 = 0.45), Senegal $($ SI1 = 0.38), Guinea Bissau (SI1 = 0.41) and Mali (IS1 = 0.30). In Republic of Guinea (IS2 = 0.36), and Gambia $(\mathrm{SI} 3=$ $0.53)$, individuals of rice trophic population from respective morphogroups _ 2 and _ 3 were subsequently better classified (Table 7). With Indexes of negative Silhouette (Figure 7), the individuals in B. Faso (TcrzBu6: IS = 0.031; TcrzBu8: IS = -0.018; TcrzBu18: IS = -0.092; TcrzBu21: IS = -0.018; TcrzBu28: IS = -0.092), G. Bissau (TcrzGb1: IS = -0.038) and Niger (TcrzNi8: IS =-0.096; TcrzNi21: IS = -0.096), belonging to the Rice trophic population, individual in B. Faso $(T c m l B u 23:$ Is $=-0.161)$ and G. Bissau (TcmiGb20: IS = 0.001 ), belonging to the millet trophic population, were poorly classified in the morphogroup _2 priori and found their morphology in the group_1 posteriori (Figure 7). An individual in G. Bissau (TcmiGb2: IS = 0.005 ) and individual in Senegal (TcmlSe8: IS $=-0.057)$, belonging to the millet trophic population, were poorly classified priori in the morphogroup_1 and found their morphology in the morphogroup_2 posteriori (Figure 7).

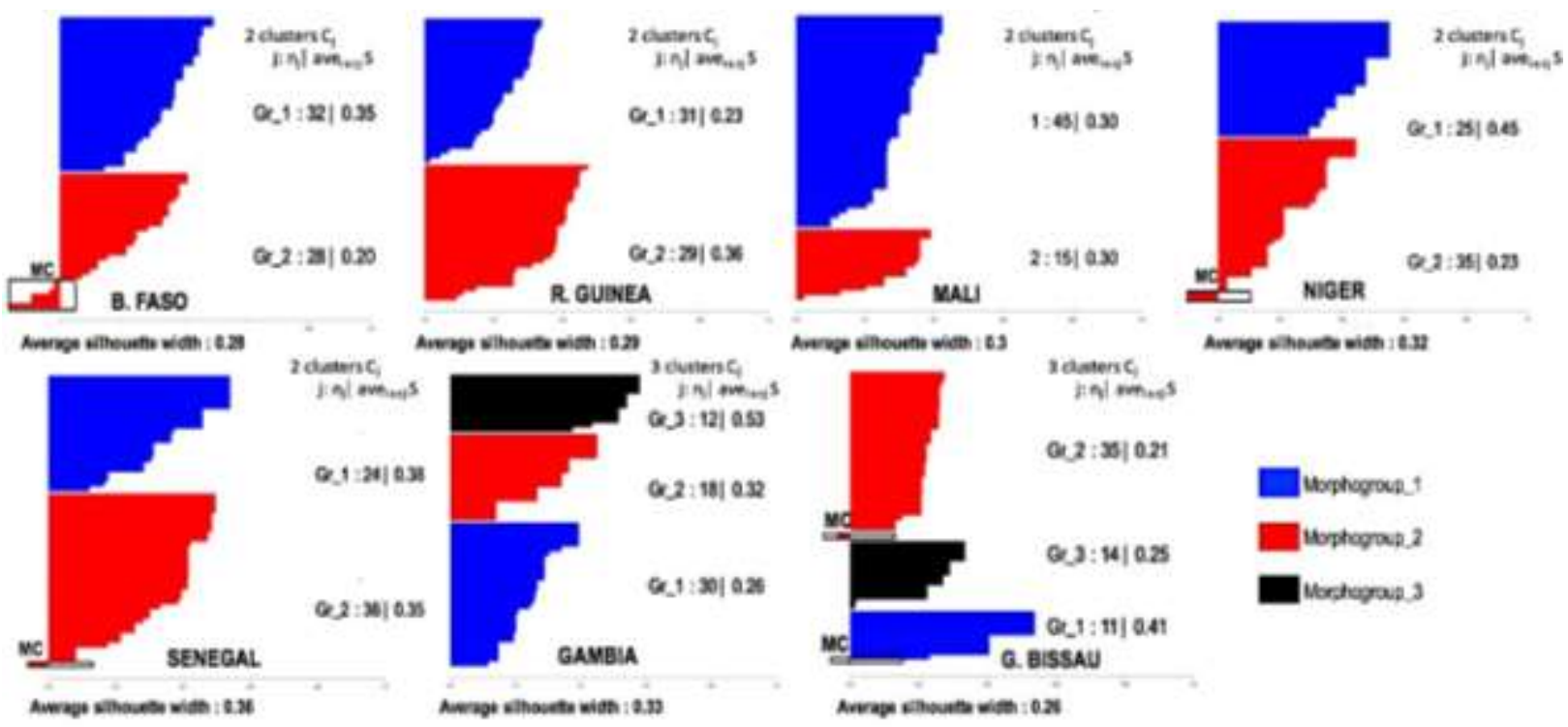

Figure 7:- Silhouette Diagram of trophic populations. Burkina Faso, Gambia, Guinea Bissau, Republic of Guinea, Mali, Niger and Senegal represent the sampled geographical sites; MC: poorly classified.

\section{Discussion:-}

For achieving a morphometric study of the West African trophic Populations of the Tribolium castaneum, 19 variables were measured for each male. The raw measurements obtained from these variables revealed constants 
sizes: distances between dorsally and ventrally eyes (Dyd, Dyv) and the width of the femur from the 3rd pair of paws $\left(L f_{3}\right)$ in all individuals of $T$. castaneum. According Delobel \& Tran (1993), the distance between the ventrally eyes is a key for identifying $T$. castaneum and its twin species Tribolium confusum. The length between the dorsally eyes and the width of the femur from the 3rd pair of paws could also be specific to the T. castaneum species.

Raw Data and differences of size between trophic populations: raw data PCA and DA combined for each sampled country showed in a first approach, that the size factor distinguished the two trophic populations of $T$. castaneum. The DA revealed the large size of the individuals in the population of millet compared to those of the population of rice in all West African countries. The large size of the $T$. castaneum individuals that have run their development cycle on millet compared to those that have grown on other cereals such as maize, has been shown by the Diome studies (2014). Given the size of the grain of rice (Average-weight $=0.019 \pm 0,0012 \mathrm{~g} /$ grain) was greater than that of the grain of millet (Average-weight $=0.010 \pm 0,0015 \mathrm{~g} /$ grain), there was no direct relationship between the size of the infested grain and the insect that infested it. This observation was in one hand in corroboration with the negative correlation between the size of seeds of Tamarindus and Arachis and that of individuals of Caryedon serratus which infested them (Sembene \& Delobel, 1996); on the other hand, was discordant with the positive correlation between the size of seeds of the varieties of cowpea and that of individuals of Bruchidius atrolineatus which infested them (Moumouni et al., 2014). Knowing that the development of the male T. castaneum performance was strongly influenced by the nutritional quality of the grain they infested (Ming \& Cheng, 2013), the large size of the individuals in the trophic millet population of T. castaneum compared to those of the Rice population, found without doubt its explanation in the nutritional quality of the grain of millet which was richer than the grain of rice (Hulse et al., 1980), as it had been shown by previous studies of Sembène \& Delobel (1996) in C. seratus on its different hosts.

Transformed variables-log, differences of forms and morphological features of trophic populations: the size factor played an important role in the morphometric differentiation between trophic west African populations of $T$. castaneum, but the analysis of transformed log-variables shows that it is far from being the only one. Following the elimination of the size effect for the specific form of the individuals, although the barycenters of the two populations came closer, the morphological discrimination strictly related to the form of the two trophic populations revealed by the DA, remains visible. The combined DA analyzes and significance of differences averages test of log-transformed between the two populations explained the morphological features directly related to the form of each trophic population. In Burkina Faso, the millet population was characterized by more developed antennas, larger elytra, longer tarsus_3 and tibia_3 and a wider abdomen; the rice population has a longer distance between the pronotum and the thorax and longer $1^{\text {st }}$ abdominal sternite. In Guinea Bissau, the millet population had longer coxa_3, elytra and pronotum, more developed antennas and pronotum, a larger $1^{\text {st }}$ abdominal sternite and a bigger head. The rice population was characterized by a longer distance between the pronotum and the thorax and longer $1^{\text {st }}$ abdominal sternite and tibia_3 and larger elytra. In the Republic of Guinea, the millet population was characterized by a more developed and antennas, larger pronotum and $1^{\text {st }}$ abdominal sternite and a longer head; the rice population had a larger distance between the pronotum and the thorax, longer femur_3, tarsus_3, $1^{\text {st }}$ abdominal sternite and larger elytra. In the Gambia, individuals of the millet population had a more developed abdomen and antennas, longer elytra, a bigger head and longer coxa_3 and femur_3; the trophic rice population was characterized by a longer pronotum. In Mali, the millet population had a more developed $1^{\text {st }}$ abdominal sternite, a longer tibia_3 and tarsus_3 and a larger head; the rice population was characterized by a larger distance between the pronotum and the thorax and longer femur_ 3 and pygidium. In Niger, the millet population had more developed antennas and $1^{\text {st }}$ abdominal sternite, longer tibia_3, tarsus_3 and elytra; the rice population was characterized by a longer distance between the pronotum and the Thorax, a larger head and a longer femur_3 and pronotum. In Senegal, the millet population had more developed antennas, pronotum and abdomen, a longer femur_3, tibia_3 and tarse_3 and larger elytra; the rice population had a longer distance between the pronotum and the thorax, a longer coxa_3 and a greater head. The significant morphological differences between the two trophic populations in all west African countries would find their explanations in the organoleptic composition of grain. The millet is richer in protein, lipid and dietary fiber than the rice. By contrast, the grains of rice, are richer in available glucose (FAO, 1970). Knowing that the peripheral part of the grain (germ scutellum, envelopes and aleurone layer) is richer in starch and protein, fats, minerals and vitamins, it occupies $40 \%$ of the millet grain volume against $10 \%$ of the of the rice grain volume (Michel, 1980). Considering the difference of the two cereals in their organoleptic composition, the type of food substrate, being the support of development of T. castaneum, seems to be determining in the difference of forms between its trophic populations. 
Classification and morphological identification of individuals of trophic populations in West Africa: the trophic millet individuals had the particularity to be morphologically regrouped in the morphogroup_1 and individuals of trophic rice in the morphogroup_2 in Burkina Faso, Senegal, Niger and in Republic of Guinea. In these west African countries, the grouping of individuals in the two morphological groups, would have followed a certain trophic affinity. The morphologies of the morphogroup_2 in Niger and the morphogroup_1 in Senegal and in Republic of Guinea were private respectively to the trophic populations of rice and mil. In Gambia, the morphology of the morphogroups _ 2 and _ 3 were private to the rice population and that of the morphogroup_1 to the millet population (morphogroup_1). In Guinea Bissau, although the three morphologies were identified in the trophic millet population, the morphology of the morphogroup_1 was private to this population but the greater part of individuals of the two populations had trophic morphology of the morphogroup_2. In Mali, two morphologies were identified, but the morphology of the two trophic populations was better explained by the morphogroup_1 which comprised the greater part of their individuals. The weakest intraclasses inertia were noted between individuals of morphological groups which comprised the majority of those of the trophic millet population in most West African countries. We noticed from this observation a greater morphological intraclasses homogeneity of individuals of the trophic millet population compared to intraclasses individuals of the trophic rice population. The morphological dissimilarity between the two trophic populations was revealed by the interclasses inertia which were larger between morphological morphogroups which characterized each trophic population than between morphological groups which characterized the same population. Individuals of trophic populations were better classified in Senegal, Niger and Gambia where each of the morphological groups was specific to one of these populations, with the greatest Indices of Silhouette. This confirms the morphological feature of each trophic population. The clusters that bring together the majority of the individuals in the trophic millet population possess the highest indices of Silhouette and thus reveal their best morphological classification for most West African countries including Burkina Faso, Niger, Senegal, Guinea Bissau, and Mali. Knowing that individuals with morphological affinities tend to be in the same cluster, the best ranking of intraclass individuals in the millet trophic population is due to their morphological homogeneity.

This study showed that there were morphological differences of size and shape between trophic millet and rice populations of $T$. castaneum. The Trophic millet population presented more homogeneous morphology in most West African countries although some of its individuals had the closest morphology to the trophic rice population. Knowing that the food diversity acted on the morphological diversity of the weevil groundnut (Carryedon seratus) (Sembene \& Delobel, 1996) and on the weevil cowpea (Bruchidius atrolineatus) (Moumouni et al., 2014), storage conditions for cereals in West African commercial stores that are favorable to the genetic diversity of this insect (Dia et al., 2014), offered to the imagos and T. castaneum adults , being good flying insects, the possibility to colonize rice stocks as a result of the exhaustion of millet stocks, corn or another previously infested culture which could have a better nutritional quality than rice. Knowing that, individuals which emerged on mil, might be generated by adults fed on rice and vice versa. The same material used for the marketing of several cereals in the same warehouses, could carry eggs, nymphs and even adults from a cereal grain to another and would also facilitate the movement of $T$. castaneum from a stock to another one. Then, the emergence of the third morphological group specific to the trophic rice population would be due to the cereal (in addition to millet) that the individuals that make up this group colonized before the infestation of rice. The storage conditions would also be at the origin of this morphological brewing between some individuals of different trophic populations. The host plant played an important role in the determinism of T. castaneum morphology. The morphological structuring observed between these trophic populations could be the consequence of a likely morphological adaptation of $T$. castaneum to varied hosts; and these trophic populations may be genetically distinct populations.

\section{Conclusion:-}

The morphometric study of the trophic T. castaneum populations in the of West African area brings an important argument for the existence of distinct populations according to the diet of individuals. The two trophic populations are morphologically differentiated (size and shape) in most West African countries. These morphological differences are important and also affect the head, thorax and abdomen of individuals as well. In the West African zone, a morphological group, consisting mainly of individuals of the millet trophic population, characterizes the morphology of the individuals of this population. The other two morphological groups, one of which includes the majority of individuals in the trophic rice population and the other constituted only with individuals of this population, characterize the morphology of this population. The host plant proved to be a structuring factor in the morphological discrimination of this trophic insect populations in the West African area. Storage conditions in 
commercial stores that offer the insect a variety of possibilities to infest different cereals, are at the root, to a certain extent, of the intra-host morphological diversity. These inter-hosts morphological differences lead us to ask whether the morphological diversity of this insect is just an adaptation possibility on the morphological scale of this pest or is it the phenotypic expression of a new genetic strains.

\section{Acknowledgments:-}

All ours thanks to Mr. Ahmed Bachir Diédhiou, teacher at the André Malraux secondary school in Strasbourg and graduate in scientific calculation at the University of Strasbourg, who has been actively involved in statistical analysis. These studies had been funded by the UEMOA (West African Monetary Union) and WAPP "World Bank program" National Centers of Excellence.

\section{Bibliographic references:-}

1. AFD-CIRDA-IFDA. (2011). Food crops rainwater in West and center Africa: collective book. To know 06. French Development Agency. 195 pages.

2. Bloomfield V.A. (2014). Using R for Numerical Analysis in Science and Engineering. Chapman \& Hall/CRC The R Series, 359p (ISBN 978-14398844).

3. Darrroch, Jn \& Mosimann, i. (1985). Canonical and principal components of shape. Biometrika. 72 (2): 241252.

4. Delobel A. and Tran M. (1993). The Beetles of foodstuffs stored in hot regions. OSTROM / CTA, tropical fauna XXXII. 439p

5. Dia C. A. K. Mr., Diome T., Thiaw C., Diop Mr. and Sembene M. (2014). Impact of storage infrastructures and agroecological areas in genetic demographic evolution of Tribolium castaneum Herbst (Coleoptera: Tenebrionidae) Senegalese populations. International Journal of Science and Advanced Technology (ISSN 2221-8386) Volume 4, Page: 12 - 23.

6. Diome T. (2014). Biodemography and genetic diversity of populations of Tribolium castaneum Herbst (Coleoptera, Tenebrionidae) pest of grains of millet (Pennisetum glaucum Brown) in stock in Senegal. Doctoral thesis unique in population genetics, Cheikh Anta Diop University of Dakar.

7. FAO (1970).Table of food composition for the use of the Africa. FAO, Rome.

8. FAO (1995). The sorghum and the mails in Human Nutrition, Rome. FAO: 1996. Ten- ninth session of the FAO Regional Conference for Africa, Ouagadougou (Burkina Faso) 16-20 April 1996. The World Food Summit: Assessment and Prospects of food security in the Africa region. 18 pages.

9. Foua-bi K. (1989): the problems of post-harvests in Africa. Current state. Prospects for the future. Inaugural Conference in: cereals in warm regions: conservation and transformation.

10. Michel JC(1980).potential use of sorghum in a intégré système in milling and pasta. In: The amélioration of systèmes post-récoltesen West Africa. Agency for Cultural coopération technical and,Paris.

11. Ming QL, Cheng C. (2012), Influence of nutrition on male development and reproduction in Tribolium castaneum. I Econ J. Econ 105:1471-1476

12. Moumouni D. A., Doumma A., Toufique B. M., Sembene M. (2014). Influence of the three varieties of the niebe on the biology and morphometry of Bruchidius atrolineatus, pests of niebe in Niger. Sppd - Tenth International Conference on pests in agriculture. MONTPELLIER - 22 and 23 October 2014.

13. Ngamo LST., Hance T. (2007). Diversity of pests of foodstuffs and alternative methods of struggle in tropical environment, in tripicultura.25 (4): 215-220

14. Ouédraogo S. J., W. Théodore Kaboré W. T. and LoDAa M. (2014). Prospective study on losses post Crops in West Africa: the case of a few coastal countries and the Sahel. Final Report, Institute of the Sahel (CILSS). 44p.

15. Hulse, J.H., Laing, E.M. \& Pearson, O.E. (1980). Sorghum and the millets: their composition and nutritious value. New York, Academic Press. 997 p.

16. Santos F. (2015). Principal components analysis (PCA): Work Practices with the software R. CNRS, UMR 5199 PACEA.

17. Seck D. (2012). Scientific animation of the Sector South Center: Recognition and approach of integrated pest control against the main insects of food stored in Senegal. 19p

18. Sembene Mr. and DELOBEL A. (1996). Morphometric identification of populations Sudano-sahelian Bruche of groundnuts, Caryedon serratus (Olivier) (Coleoptera, Bruchidae). Journal of African Zoology 110 (5). 10p.

19. Sezonlin M. (2006). Phylogeography and population genetics of the driller of stems of cereals Busse olafusca (Fuller) (Lepidoptera, Noctuidae) in sub-Saharan Africa, implications for the biological fight against this insect. Doctoral thesis at the University of Paris XI-Orsay. 152p. 